Ideology, democracy and secularism in contemporary Iran. Lessons for the Arab Spring?

\title{
Civil Society and Democracy in Iran
}

Ramin Jahanbegloo (ed.)

Lanham, Lexington Books, 2012

Democracy in Modern Iran. Islam, Culture and Political Change

Ali Mirsepassi

New York, New York University Press, 2010

Muslim Reformers in Iran and Turkey. The Paradox of Moderation

Güneș Murat Tezcür

Austin, University of Texas Press, 2010

Political Islam, Iran and the Enlightenment. Philosophies of Hope and Despair

Ali Mirsepassi

New York, Cambridge University Press, 2011

The Iranian 2009 massive anti-regime protests in the wake of the contested presidential elections and the Arab Spring have taken the scholars of Middle Eastern Studies and the international community by surprise. It seems that, despite the very diverse outcomes of the uprisings in Iran and across the Arab world, Middle Eastern societies are in the very middle of what has been called an 'unfinished revolution' (Sakbani 2011). Despite the confusion that affected the academic community following the surprising events of the past few years, a great amount of studies have been produced in order to identify the roots and make sense of the uprisings. For the most part, however, explanations for the events refer to and are based on well-known theoretical debates and paradigms. In the case of the Arab world, the fall of long-standing authoritarian regimes has revived scholarly interest for the transition to democracy paradigm, whereas studies on the resilience of authoritarian regimes are now perceived as over-estimating authoritarian rulers' grip on society. In addition, the electoral success of Islamist parties has re-ignited scholarly enthusiasm for the rather trite debate on the compatibility between Islam and democracy.

In the case of Iran, similar debates centred on democratization versus authoritarian persistence and on the relationship among Islam, democracy and modernity have been animating academic discussions for the last two decades. The 2009 crisis strengthened 
scholars' perception of Iranian society as democratic, liberal, secular and in conflict with the authoritarian Islamic regime. Indeed, many social scientists of Iranian Studies support the idea that the explosion of political and social crisis in Iran, such as the 2009 uprising, demonstrates the existence of that liberal, secular and 'modern' civil society willing to shake a backward and authoritarian regime off. These four books elaborate on this interpretative line of inquiry, setting forth interesting arguments for an analysis of the current state of Iranian Studies and offering useful elements of reflection to scholars of the Arab world as well.

\section{The ideology of democracy in Iranian Studies}

The field of Iranian Studies is very often characterised by strong political fervour, a trait obviously not confined to it, yet very passionate. Many among the scholars of Iranian Studies are indeed engaged in promoting a culture of peace and democracy within the international community and Iran, thanks to their public visibility and intellectual discernment. However this normative mission, which is certainly compatible with scholarly work, has to some extent turned into a far more rigid, and in some cases even ideological, posture that informs scientific claims and analyses. Some traits of such an ideological stance are present in the books under review. This is particularly evident in the interpretation of Iranian national history they subscribe to, which centres on a highly symbolic idea of democracy, on the clear-cut separation between society and the state and on a traditional understanding of modernity, which is composite of a secular public sphere, liberal democracy and individualism. This interpretation, which has become dominant in reformist political circles in Iran (Khatami 2005) and among many scholars, argues that a 'quest for democracy' (Azimi, 2008) characterizes Iranian history and that Iranian civil society has been conducting this quest against the state throughout the centuries. The state and its authoritarian nature are considered the main obstacle on the path towards the establishment of a liberal and democratic political order.

The first event regarded as an example of this recurring historical pattern is the Constitutional revolution of 1906-1911, to which many of the authors contributing to the books under review refer to. During those years, so the story goes, Iranians became familiar 'with modern thinking and the concept of democracy, associational life, modern state, rule of law, political participation and civil establishments such as parliament, political parties and civil institutions,' (Razzaghi 2010, 3) but all hopes for the establishment of a democratic government were dashed due to the return of repressive monarchical rule thanks to the 
helping hand of foreign powers. The second event highlighting the 'quest' and its ultimate failure is the experience of the Mossadegh's government, which, in 1951, nationalised the Iranian oil company, raising British and American concerns and eventually leading to the 1953 coup d'état and the restoration of Pahlavi authoritarianism, which repressed all dissenting voices. The 1979 revolution is also seen as crucial event on the road to democracy, since it represents the people's victory over the monarchy. However, despite the great expectations that the revolution raised, scholars agree that the establishment of democracy and of the flourishing of an autonomous and modern civil society was halted when the Khomeinists high-jacked the revolutionary moment and its fate sealed with the breakout of the Iran-Iraq war. Twenty years later, the reformist Khatami's governments (1997-2005) tried to partly restore democratic rule through the establishment and protection of civil society organisations, attempting to make them the pillars of a process of democratisation. At the time, the idea of civil society as an adversary of authoritarianism regained momentum (Rivetti 2012) and increased its strength throughout the first Ahmadinejad's presidential term (2005-2009) and during the 2009 crisis.

This narrative of national history, based on the ideas of 'civil society resilience' and 'persistent struggle for democracy' finds significant support in political and intellectual circles both inside and outside of Iran. Jahanbegloo's edited book builds explicitly on it: as he writes in the introduction, the core questions of the volume are

\footnotetext{
'Under what conditions do we get to talk about the role of Iranian civil society in the process of transition to democracy in Iran? What has been the enduring legacy of the previous social and political movements, starting with the Constitutional revolution of 1906, in the struggle for democracy in Iran? (...) Last but not least, in which way could we say that the work of Iranian civil society has strengthened the idea of secularism in Iran?' (xiii).
}

The book collects sixteen contributions of well-known scholars and of Iranian social and political activists, who offer interesting insights such as Shadi Sadr's reading of the women's movement strategy, or lack thereof, in the post-2009 environment (199-217). From a general point of view the volume looks more like an 'activist book' than an academic one. Indeed, its main objective is to discuss a number of issues related to democratisation and secularisation in Iran, contextualizing them in the historical trajectory described above. The first two sections of the volume ('Theorizing Civil Society in Iran,' 3-93 and 'Islam, 
Secularism, and Efforts for Democratization,' 97-156) are aimed at understanding and underlining the enduring legacy of this 'quest for democracy.' For instance, in his chapter on 'Religious Disputation and Democratic Constitutionalism,' Nader Hashemi argues that 'the origins of today's ideological conflict between Mahmoud Ahmadinejad and Mir Hossein Mousavi can be traced back to the Iranian Constitutional revolution of 1906-11' (97). The remaining two sections ('Gender and Politics,' 159-217 and 'Identity and Group Rights,' 219-290) deal with the (dis)respect of human rights and efforts to promote gender equality and minorities rights. The common thread linking all the chapters is the reference to Iranian secular democratic traditions, which shaped the Green Movement's identity. In Farhad Khosrokhavar's bold words, the outcome of such an influence is the fact that Iranian society is today divided between 'a non-organized secularized Islamic society on the one hand, and anti-modern, violent, Islamist groups on the other side, backed and organized by the theocratic government' (72-73).

Ali Mirsepassi’s Democracy in Modern Iran echoes these arguments too. He refers to an unchanging historical pattern explaining the 2009 crisis:

'the present reform movement in Iran started shortly after the end of the Iran-Iraq war (1980-88), and clearly announced its aspirations to build democracy, establish the rule of law, and realize a society where people can live honorably as citizens. All these aims are consistent with the tradition of the 1906 Constitutional Movement. (...) (The Green Movement) must be read within the context of this broader historical discourse in which the struggle for democracy and the rule of law has been waged against both such authoritarian ideologies and political regimes' (xi).

At the core of Mirsepassi's volume stands an evaluation of the likelihood of a cultural and political democratisation in Iran which, contrary to the optimistic and activist tone of Jahanbegloo's book, is quite pessimistic. Mirsepassi focuses on Iranian intellectual milieux and argues that the Iranian intellectual approach to democracy is inefficient since it is concerned with an epistemological and philosophical perspective rather than with the establishment of democratic institutions for governing society as the first step to be taken in order to promote a democratic culture. Thus, the author criticises the much celebrated 'new intellectuals of Iran' and their supposedly democratising function (Jahanbegloo 2000) by stating that 
'the dominant intellectual perspective (...) has been philosophical, and has been in the tradition of philosophical rationalism. This philosophical reading of modern ideas and society has reduced the hold on democracy to an embrace of 'progress,' 'scientific rationality,' and 'reason.' Democratic ideas and institutions have therefore either been seen as a by-product of modern rationality or as the absence of intellectual sensibilities concerning culture' (20).

Despite providing the readership with good arguments and mastering an impressive amount of philosophical and theoretical material, Mirsepassi's volume does not add novel perspectives to debates that have already been widely discussed in the field of Middle Eastern and Islamic Studies. This is the case, for instance, of his discussion of the complex relation between democracy and secularism and of the contested nature of the idea of modernity (2580). Furthermore, despite supporting the idea of modernity as an 'unfinished project', Mirsepassi is quite clear in suggesting that the road to democracy for Iran has to be inspired by Western models of modernity and secularism, in particular by British Enlightenment and the Kantian liberal tradition of thought.

\section{Democratisation and Social Secularism in Iran: a Reaction to Previous Scholarship}

At the core of Jahanbegloo's edited book and Mirsepassi's Democracy in Modern Iran are the issues of democratisation and social secularism in Iran. The persistence of these arguments and the way in which they are approached are of course related to the peculiar nature of the Islamic Republic and its social transformations. But it also can be seen as a reaction to two historiographical trends that developed in the 1970s and 1980s within Iranian Studies. The first is a culturalist approach, which tends to explain social and political facts through the prism of religion and its social appeal; and the second is the 'state-centric' approach, which understands Iranian 'history through the ideologies, institutions, and personalities that dominate a given society' (Matin-Asgari 2002, 3; Schayegh 2010). In post1979 Iran these two perspectives have merged. This has determined among the scholars of Iranian Studies, many of whom are of Iranian origin and lived personally part of the revolutionary events, the understandable will of reacting to a representation of Iran as a religiously dominated, politically static and socially backward country. Indeed, as Afshin Matin-Asgari noted (2002), mainstream historiography has for years depicted the history of modern Iran as characterised by a struggle between the state and the Shiite clergy, apparently 
the two only existing political and social forces in the country. This is why, according to Said Amir Arjomand (1988) or Ira Lapidus (1988), the only possible outcome of the 1979 revolution was an Islamic republic. Such an interpretation, which denies the existence and relevance of secular, leftist, nationalist movements and groups, has encountered the criticism of younger scholars. They have not only devoted their studies to the repressed, unofficial and dissenting movements, but also reclaimed their enduring influence on today's activists and movements. According to them, the post Iran-Iraq war 'democratic revival' which saw the reemergence of a limited public sphere and the following ascendancy to executive power of Khatami and the reformists, was the demonstration of the effectiveness of such a historical legacy. In reaction to the 'state-centered' perspective, many scholars have proposed the idea of a 'democratisation from below,' the separation between society and the state, and focused on the democratising activities of the Iranian 'civil society,' an expression that became a real key-word in the field (Butel 1998, Khosrokhavar 2000, Saghafi and Ehsani 1999, Kamali 2001, Yaghmayan 2002). In this context, the terms of the debate and the objects of analysis have however been confused with wishful thinking and ideology. For instance, the idea that the collapse of the Soviet Union and the 'end of ideologies' brought about a democratic era governed by the non-ideological imperatives of moderation and pragmatism was much supported; from this, followed the assumption that in such a new era, Iranian society became de-ideologised, disillusioned with the Islamist regime and therefore democratic (Saghafi 2001, Khosrokhavar and Roy 1999, Sheikholeslami 2000). Furthermore, concepts such as 'democracy,' 'civil society,' 'modernity' have often been used as one, or bounded together in a teleological, positivist relationship. As in much of the Middle Eastern Studies during the 1990s and early 2000s, social sciences were dominated by what can be called a 'transitology fever' according to which the Islamic Republic was on the verge of democratisation given the presence of factors such as economic liberalisation, 'civil society organisations,' a deideologised and reasonably large middle class and a moderate government. Furthermore, to give more substance to the claim about Iranians' liberal bias, scholars argued that Iranians are more democratic and less religious than Arabs (Moaddel, Azadarmaki 2002; Moaddel 2009). As Khosrokhavar stated, 'in terms of democratic social movements, the contrast between Iran and the Arab world is glaring. (...) In the Muslim world at large (...) democracy is supported neither by the government nor by any large scale social movement' (49). Following from this black and white representation, is the assumed fact that in many Muslim countries there still is the belief in political Islam 'as the ultimate political and social solution' (49), whereas in 
Iran 'the Utopia of political Islam is dead for the overwhelming majority of the population' (50).

When presented in such fashion, the narration of Iranian history as a struggle from below for democracy, free civil society and human rights against state authoritarianism is very unproblematic and therefore questionable. This is not to deny the fact that political resistance, dissent and revolt have characterised the Iranian history: we all indeed know that where there is power, there is resistance. What is questionable here is the reading of resistance as a liberal project, aimed at establishing a poorly defined 'democracy,' which is the goal of almost any form of resistance at any point in time. It follows that there are significant issues with this normative and deterministic historical perspective, which often projects individual desires and beliefs rather than detached analyses of both the past and the present. First, it is not clear what it adds to our understanding of Iranian history and politics. The history of almost every nation in the world may be read as the people's struggle for some objective such as national unity, freedom from colonialism, or the establishment of an independent, democratic government. From the point of view of historical scholarship, arguing that Iranian history is characterised by an unchanging pattern of 'democratic resilience,' a general paradigm applicable to any event at any point in time, is either a wishful thinking or an ideological statement. In this sense, the authors' continuous reference to the Constitutional revolution and to this unchangeable historical pattern transcending the decades, sounds like the propagandistic use that politicians make of events of the past in order to legitimate today's options by contextualising them in a normative, broader and national historical trajectory.

Second, there is a problem with the definition of 'democratic,' which is often delinked from any historical context and to which an unchanging, positive meaning is often attached. It is interesting to note how the authors use today's language and key-words in order to describe social and political dynamics that took place more than one hundred years ago, in very different international and domestic settings. This is the case also with 'civil society', which has become an all-encompassing concept often employed not to describe a concrete and precise phenomenon, but in order to allude to something symbolically and ideologically linked to positive democratic values.

The third weakness of this understanding of Iranian history and social transformations is the dismissal of Islamism as a working and appealing political force. This is quite similar to the reaction that some scholars of the Arab world had when the Egyptian and Tunisian uprisings exploded. Olivier Roy, for instance, wrote that the revolts were dominated by a new 
generation composed of individuals 'not interested in ideology,' who 'do not invoke Islam like the older generation did in Algeria in the late 1980s' (Roy 2011). Such a quick dismissal of Islamism as an effective ideology is in profound conflict with later events such as the electoral success of Islamists or the emersion of Salafist forces in Tunisia, Libya and Syria. In the case of Iran, many scholars argue that Iranian society is broadly secular, often overlooking the complexity of such a statement. Indeed, their analysis is sometimes based on questionable factors and thus questionable in its findings. In his chapter, for instance, Khosrokhavar argues that 'large sections of the Iranian civil society have been secularized, due to internal evolution, the access of many young people to education, the influence of the Iranian Diaspora abroad (...) and Internet culture which has partially neutralized the ideological views propagated by the regime' (60), or due to 'mobile phones, satellite TV, YouTube, Twitter, Facebook' (43). Despite maybe holding some degree of truth for particular social strata, such claims are based on sources that are only partially valid. For instance, such a secularisation is often linked to the emergence of the post-1989 democratic intellectual discourses of Soroush, Kadivar and other intellectuals (46). However their influence over the wider population beyond university students and activists is likely to be limited. Similarly, the growing mingling of sexes (45) cannot necessarily be cited as supporting the argument of secularization given the significance of class stratification and the internal cultural differences of the population. The rise of female education (45-46) also does not necessarily equate with gender emancipation and secularization, as demonstrated by Goli Rezai-Rashti (2011). Finally, the popularity of Gene Sharp's The Politics of Non-Violent Action (57-58) should not be over-stated when one considers that the impact that this book has outside the very small community of activists in Iran might be severely limited.

The prominence of secularism amongst the most debated issues in Iranian Studies is probably understandable because it offers a partial redemption from culturalist and neoorientalist views on Middle Eastern societies. Mirsepassi's Political Islam, Iran and the Enlightenment partly follows this approach, as stated by the author himself, who aims

'to raise awareness among scholars by defining the 'non-Islamic' ideas that have been essential to the overall development of the Islamist ideology, disturbing at once the Islamist claim to local 'authenticity' as well as the too-common assumption in the West that these radical politics somehow represent a 'natural' or 'logical' extension of Islamic religious or cultural history as such' (5). 
Mirsepassi's core argument is that a significant part of the ideological body of Iranian Islamism is rooted in the West and in Western anti-Enlightenment intellectual tradition. Although part of this argument has already been documented elsewhere (Boroujerdi 1996), the volume goes further in examining the mutual influences among world civilisations that prepared such an exchange, removing Iran and Islamism from scientific insularity. The book opens with an examination of nativist and 'localist' reactions to modernity, reporting different examples from both Western and non-Western societies (21-66), and concludes with Mirsepassi's own opinion on the possibility and strategy for reconciling religion and democracy with a progressive and pro-Enlightenment modernity. The volume is composed of an impressive review of a very broad body of literature: from Dewey to Roberspierre, from Heidegger to Putnam, the author offers an intellectually refined discussion of various theories he perfectly masters. All this is aimed to defend the progressive and liberal values that result from a democratic understanding of the Enlightenment and its modernist vocation. However, despite the merit of engaging a huge part of Western philosophy in a very fascinating manner, the book presents one main weakness being a passionate promotion of a political ideology, liberal democracy in this case, rather than a critical examination of it and an analysis of the appeal that criticism of liberal democracy may have in Iran for many social groups. The assumption here is that since 1979 Iranian society has changed to the point that criticism against some traits of the Islamic regime is equated with uncritical support for liberal democracy - an assumption which raises doubts. The last chapters of the book are devoted to promote a model of modernity which is informed by the Western historical experience and rests on the foundations of Western liberal democracy. Despite his call for a pluralist modernity, Mirsepassi explicitly states his preference is for the British-American pragmatic model (chapter six), which is considered as the best option for Iran. This is done without any element justifying such a claim, beyond the author's clear preference for it.

Generally speaking, recent studies on the topics of democratisation and social secularism in Iran have the merit of resting on very refined and elegant theoretical elaborations, but have the downside of being quite ideological in their premises. A further demonstration of this is the fact that we still do not have a scientific examination of the idea of democracy as understood and promoted by non-reformist intellectuals and theorists. Indeed, important transformations have taken place within the conservative and traditionalist elite as well, although often neglected in the scholarship. The 2009 crisis and the intense factional competition have caused the emergence of rifts and conflicts, which in some cases have been caused by diverging views on the room for and limits of dissent, within the 
conservative and traditionalist elite in power. This is probably because, according to received wisdom, topics such as democracy are exclusive to reformists' ideological system. Furthermore, given their growing prominence in Iran and more generally in the region, conservatives Islamists and their values would deserve more attention.

\section{A possible way out?}

In recent years, the issues of democracy, social discontent and progressive activism in Iran have received a great deal of attention and have been linked to the experience of Khatami's reformist governments, whose political activities have been examined under the more general rubric of democratization studies. Güneş Tezcür's volume, Muslim Reformers in Iran and Turkey is aimed at examining reformist political forces in Iran and Turkey, but the author does this in an original manner, avoiding many of the scholarly pitfalls described above. First, as far as the Iranian case is concerned, the author avoids approaching Khatami's efforts of liberalization of the public sphere and political discourse through the lenses of democratisation studies. Instead, he approaches the reformist era through moderation theory. Building on Jillian Schwedler and Carrie Rosefsky Wickham's studies on Islamists in Yemen, Jordan and Egypt, Tezcür's main argument is that moderation can actually be an obstacle to democratisation rather than an incentive, contradicting what the moderation theory and democratisation studies posit. Second, Tezcür suggests that reformism and moderation can be analysed from a different perspective other than their supposedly pragmatic and anti-ideological nature. Furthermore, he refers to the 'international dimension' of reformism, meaning that reformist forces are normally more welcomed by the international community because they are considered as non-ideological and therefore more cooperative in the economic and diplomatic spheres than other factions (9-10).

Despite the many positive aspects of Tezcür's analysis, which brings to scholarly attention a number of useful theories usually neglected in Iranian Studies, the author misses a more general critique of what could be called the 'ideology of reformism,' or the preference for moderation over revolutionary and radical means of political struggle as an attitude informing scholarly claims and theoretical premises. An example of such an ideological approach can be found in Mirsepassi's Democracy in Modern Iran. In the preface, the author states that 'an important but poorly understood fact that needs to be emphasized is that Iranians historically prefer reform of existing political institutions to total change - this is why important figures in the modern history of Iran are known as 'reformers' (xiii), a claim which is tautological and hardly demonstrable with only the author's perception as empirical 
support. In her analysis of Ben Ali's Tunisia, Béatrice Hibou (2009) demonstrated that 'reformism' is an ideological tool which, in the $21^{\text {st }}$ century, political forces refer to in order to gather domestic and international endorsement. Appealing to democracy has a similar legitimising effect, being something that almost any social or political actor has to refer to. The internationally dominant rhetoric of democracy, reformism, human rights and nonviolence frame the activists' discourse and indicate them the right language to be spoken in order to reach an international audience. No surprise, then, that the Green Movement defines itself as non-violent, reformist, pro-human rights or democratic. Within this framework, the interpretation of Iranian history as a 'quest for democracy and civil society' and the normative, positive value attached to reformism and moderation look like assumptions informing an ideological manner of approaching these issues, ignoring the instrumental use that political actors can make of democratic ideals, moderation and their sometimes evanescent meaning. This does not mean denying the democratic nature of the Green Movement. It indicates rather that scholars should go beyond the activists' self-representation and contextualize instead the experience of democratic struggles in a broader analytical setting, where the activists' discourse does not answer all our scholarly queries. Tezcür's book does not expand in this direction, but should be praised for its original review of a great deal of theories on political change that are sometimes overlooked by other scholars.

\section{Conclusion}

The overcoming of an ideological approach to the study of social conflicts and transformation in Iran is only possible through the disempowerment of the symbolic strength of concepts such as democracy or civil society, bringing them back to research and engaging the genealogy of their meaning and use (Foucault 1977). These four books do not operate in this direction, despite providing the academic community with fascinating readings. However, the most important element that these volumes paradoxically lead to is an urgent call for a discussion about the state of Iranian Studies, which would benefit from a serious engagement with social scientists from Arab Studies. Indeed, the 'unfinished' status of the Arab Spring may help some scholars of Iranian Studies to abandon their teleological analytical perspective, which individuates a predefined form of government, namely liberal democracy, as the goal of all social conflicts, elite factional transformations, and even the national history of Iran. 


\section{References}

Arjomand, S.A. (1988) The Turban for the Crown: The Islamic Revolution in Iran (London: Oxford University Press).

Azimi, F. (2008) The Quest for Democracy in Iran. A Century of Struggle against Authoritarian Rule (Cambridge: Harvard University Press).

Boroujerdi, M. (1996) Iranian Intellectuals and the West: The Tormented Triumph of Nativism (Syracuse: Syracuse University Press).

Butel, E. (1998) L'individu postislamiste en Iran: la nouvelle jeunesse, Cemoti, 26, http://cemoti.revues.org/37, online.

Foucault, M. (1977), Nietzsche, Genealogy, History, in Bouchard, D.F. (Ed.) Language, Counter-Memory, Practice: Selected Essays and Interviews (Ithaca: Cornell University Press).

Hibou, B. (2009) Le réformisme, grand récit politique de la Tunisie contemporaine, Revue d'histoire moderne et contemporaine, 5(56-4bis), pp. 14-39.

Jahanbegloo, R. (2000), The Role of the Intellectuals, Journal of Democracy 11(4), pp. 135138.

Kamali, M. (2001), Civil Society in Islam. A Sociological Perspective, European Journal of Sociology, 42(3), pp. 457-482.

Khatami, M. (2005) La religion et la pensée prises au piège de l'autocratie. Voyage au coeur de la pensée politique des musulmans pendant l'essor et au déclin de la civilisation islamique (Leuven: Peeters).

Khosrokhavar, F. (2000) Toward an anthropology of democratization in Iran, Critique: Critical Middle Eastern Studies 9(16), pp. 3-29.

Khosrokhavar, F. and O. Roy (1999) Iran: Comment sortir d'un révolution religieuse (Paris: Seuil).

Matin-Asgari, M. (2002), Iranian Student Opposition to the Shah (Costa Mesa: Mazda Pbls). Moaddel, M. and T. Azadarmaki (2002), The Worldviews of Islamic Publics: The Cases of Egypt, Iran, and Jordan, Comparative Sociology, 1(3-4), pp. 299-319.

Moaddel, M. (2009) The Iranian Revolution and its Nemesis: The Rise of Liberal Values among Iranians, Comparative Studies of South Asia, Africa and the Middle East, 29(1), pp. 126-136.

Razzaghi, S. (2010) Civil Society in Iran: Transition into which Direction? Challenges, Opportunities and Strategies (Amsterdam: UvA and Hivos). 
Rezai-Rashti, G. (2011) Iranian women's increasing access to higher education but limited participation in the job market, Middle East Critique, 20(1), pp. 83-98.

Rivetti, P. (2012), Co-opting civil activism in Iran, in Aarts, P. and F. Cavatorta (Eds.), Civil society in Syria and Iran: activism in authoritarian contexts (Boulder: Lynne Rienner).

Roy, Olivier (2011) Post-Islamic Revolution, The European Institute, February 17. Available at http://www.europeaninstitute.org/February-2011/qpost-islamic-revolutionq-events-inegypt-analyzed-by-french-expert-on-political-islam.html (Accessed 29 September 2012).

Saghafi, M. and K. Ehsani (1999) 'The Temptation of Democracy': A Conversation with Morad Saghafi, Middle East Report, 122, pp. 47-51.

Saghafi, M. (2001), Crossing the desert: Iranian intellectuals after the Islamic revolution, Critique: Critical Middle Eastern Studies 10(18), pp. 15-45.

Sakbani, M. (2011) The revolutions of the Arab Spring: are democracy, development and modernity at the gates?, Contemporary Arab Affairs, 4(2), pp. 127-147.

Schayegh, C. (2010), 'Seeing Like a State': An Essay on the Historiography of Modern Iran, International Journal of Middle East Studies, 42(1), pp. 37-61.

Sheikholeslami, R. (2000) The Transformation of Iran's Political Culture, Critique: Critical Middle Eastern Studies 9(17), pp. 105-133.

Yaghmaian, B. (2002) Social change in Iran: an eyewitness account of dissent, defiance, and new movements for rights (Albany: SUNY Press). 